\title{
First record of the genus Coenocyathus Milne Edwards \& Haime, 1848 (Cnidaria: Anthozoa: Scleractinia) in the Bay of Biscay (northeastern Atlantic)
}

\author{
Álvaro Altuna', Pablo J. López-González²
}

$\xi^{*}$

\begin{abstract}
During the Fauna II expedition by the National Museum of Natural History (Madrid, Spain), two specimens of Coenocyathus cylindricus Milne Edwards \& Haime, 1848 (Cnidaria: Scleractinia) were collected off Ribadeo (Lugo, Spain), in the Bay of Biscay, at a depth of 114-116 m. This is an uncommon coral, cited only once before in the Iberian Peninsula, in the south of Portugal. The genus Coenocyathus Milne Edwards \& Haime, 1848 has been, thus, first recorded in the Bay of Biscay, being also the northernmost occurrence in the Eastern Atlantic. In this paper, the specimens are described and depicted, and the geographic and bathymetric distributions of the species are updated.

With this new record, there are 46 scleractinian species recorded up to now in the southern sector of the Bay of Biscay, which is herein considered of high species richness within the northeastern Atlantic fauna. Forty-two out of this 46 species are deep-sea corals living below than $50 \mathrm{~m}$ deep.
\end{abstract}

Key words: Coenocyathus cylindricus, Scleractinia, description, Bay of Biscay, Spain.

\section{Resumen}

Durante la campaña Fauna II del Museo Nacional de Historia Natural (Madrid, España), se obtuvieron dos ejemplares de Coenocyathus cylindricus Milne Edwards \& Haime, 1848 (Cnidaria:

\footnotetext{
1 INSUB, Museo de Okendo, Zemoria 12, Apdo. 3223

$20013 \cdot$ Donostia-San Sebastián (Spain)

E-mail: alvaro.altuna@telefonica.net

2 Departamento de Zoología, Facultad de Biología, Universidad de Sevilla Reina Mercedes 6, 41012 • Sevilla, Spain.

E-mail: pjlopez@us.es
} 
Scleractinia) frente a Ribadeo (Lugo, España), en el Golfo de Vizcaya, a 114-116 m de profundidad. Se trata de un coral poco común, del que hay un único hallazgo anterior en aguas de la Península Ibérica, efectuado al sur de Portugal. El género Coenocyathus Milne Edwards \& Haime, 1848 se cita por vez primera del Golfo de Vizcaya, siendo igualmente la cita más septentrional del mismo en el Atlántico oriental. En el presente artículo los ejemplares recogidos se ilustran y describen, y se actualiza la distribución geográfica y batimétrica de la especie.

Con este nuevo hallazgo, son ya 46 las especies de escleractinias que se conocen del sector meridional del Golfo de Vizcaya, cuya fauna es aquí considerada de una notable riqueza específica dentro del Atlántico nor-oriental. Cuarenta y dos de estas 46 especies son corales de profundidad, esto es, viven a profundidades mayores de $50 \mathrm{~m}$.

Palabras clave: Coenocyathus cylindricus, Scleractinia, descripción, Golfo de Vizcaya, España.

\section{Laburpena}

Historia Naturaleko Museo Nazionalaren (Madrid, Espaina) Fauna Il kanpainan, bi Coenocyathus cylindricus Milne Edwards \& Haime, 1848 (Cnidaria: Scleractinia) lortu ziren Ribadeon (Lugo, Espaina), Bizkaiko golkoan, 114-116 metrotako sakoneran. Ezohiko koral bat da, aurretikan aurkikuntza bakarra egon da Penintsula Iberiarreko uretan, Portugaldeko hegoaldean. Coenocyathus Milne Edwards \& Haime, 1848 motaren lehendabiziko aipamena da Bizkaiko golkoan, Atlantiko ekialdean ez da iparralderago aipatua izan. Artikulu honetan jasotako aleak azaldu eta deskribatzen dira, eta espeziaren distribuzio geografikoa eta batimetrikoa eguneratzen da. Aurkikuntza berri honekin, jada 46 dira Bizkaiko Golkoko hegoaldean ezagutzen diren eskleraktinia espezieak. Eremu honetako fauna, Atlantikoko ipar-ekialdean aberastasun handikotzat jotzen da. 46 espezie hauetariko berrogeita bi eremu sakonetako koral moduan sailkatuta daude, hots, 50 m-tik beherako sakoneran bizi dira.

Gako hitzak: Coenocyathus cylindricus, Scleractinia, deskripzioa, Bizkaiko Golkoa, Espaina.

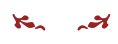

\section{Introduction}

Coenocyathus cylindricus Milne Edwards \& Haime, 1848 is a poorly-known species that inhabits infralittoral to upper bathyal bottoms in a wide geographic range in the northeastern Atlantic and the Mediterranean Sea (Lacaze-Duthiers, 1897; Zibrowius, 1980, 1983; Krucic et al., 2002; Moro et al., 2003; Boury-Esnault et al., 2005; Braga-Henriques et al., 2013). Despite its wide distribution, it is a rarely collected coral and data in the literature are few, with the species being seldom described and depicted.

Although there are doubtful fossil records in Pliocene deposits of Los Asperones (Málaga, southern Spain, Consejería de Obras Públicas y Vivienda, 2011), and El Papiol (Barcelona, 
northeastern Spain, Gómez-Alba, 1988; Gallemí et al., 2013), the unique previous record of extant specimens in the Iberian Peninsula is of material inhabiting shallow water caves in the south of Portugal (Sagres, Boury-Esnault et al., 2005). The northernmost record of the genus Coenocyathus Milne Edwards \& Haime, 1848 in Europe corresponds to C. anthophyllites Milne Edwards \& Haime, 1848 also in Portugal (Setubal area, Rossi, 1960; Zibrowius, 1980), a species infrequently collected as well.

During the Fauna II expedition by the National Museum of Natural History (Madrid, Spain), two specimens of C. cylindricus were collected off Ribadeo (Lugo, Spain), in the Bay of Biscay, at a depth of 114-116 m. The species is herein first collected in the Bay of Biscay, and it is also the northernmost record for the genus in the Eastern Atlantic. In Spanish waters it was only known from the Canary Islands (Moro et al., 2003). In the present paper, the specimens are described, and the distribution and depth range of the species updated. Besides, the biodiversity of the order Scleractinia in the southern sector of the Bay of Biscay is discussed.

\section{Material and methods}

The material was collected during the Fauna II expedition by the National Museum of Natural History (MNCN, Madrid, Spain), on board "B.O. García del Cid". The expedition was conducted during June 1991, with 95 stations sampled from Galicia (northwestern Spain) to Guipúzcoa (southeast of the Bay of Biscay), including the Galicia Bank. The main objective of the expedition was to collect deep-water material from certain poorly-known Spanish areas for biodiversity studies (Fauna Iberica Project). Information and data on this project and the different expeditions that have been undertaken is available at http://www.fauna-iberica.mncn.csic.es/proyecto/camp.php. See also Templado et al. (1993) for the methodology used for sampling. A beam trawl with a mouth of $3.5 \mathrm{~m}$ and a cod end with a mesh size of $35 \mathrm{~mm}$, was used for sampling the benthic macrofauna.

The material obtained in this expedition is deposited in the MNCN.

The terminology used for the morphological description is adopted from Cairns (2000): $H$, height; GCD, great calicular diameter; LCD, lesser calicular diameter; GCD: LCD, ratio of greater to lesser calicular diameters; Cx, Px, Sx, costae, pali or septa, respectively, of cycle designated by numerical script.

\section{Results}

Order Scleractinia Bourne, 1900

Family Caryophylliidae Gray, 1846

Coenocyathus cylindricus Milne Edwards \& Haime, 1848 (Fig. 1A-G) 


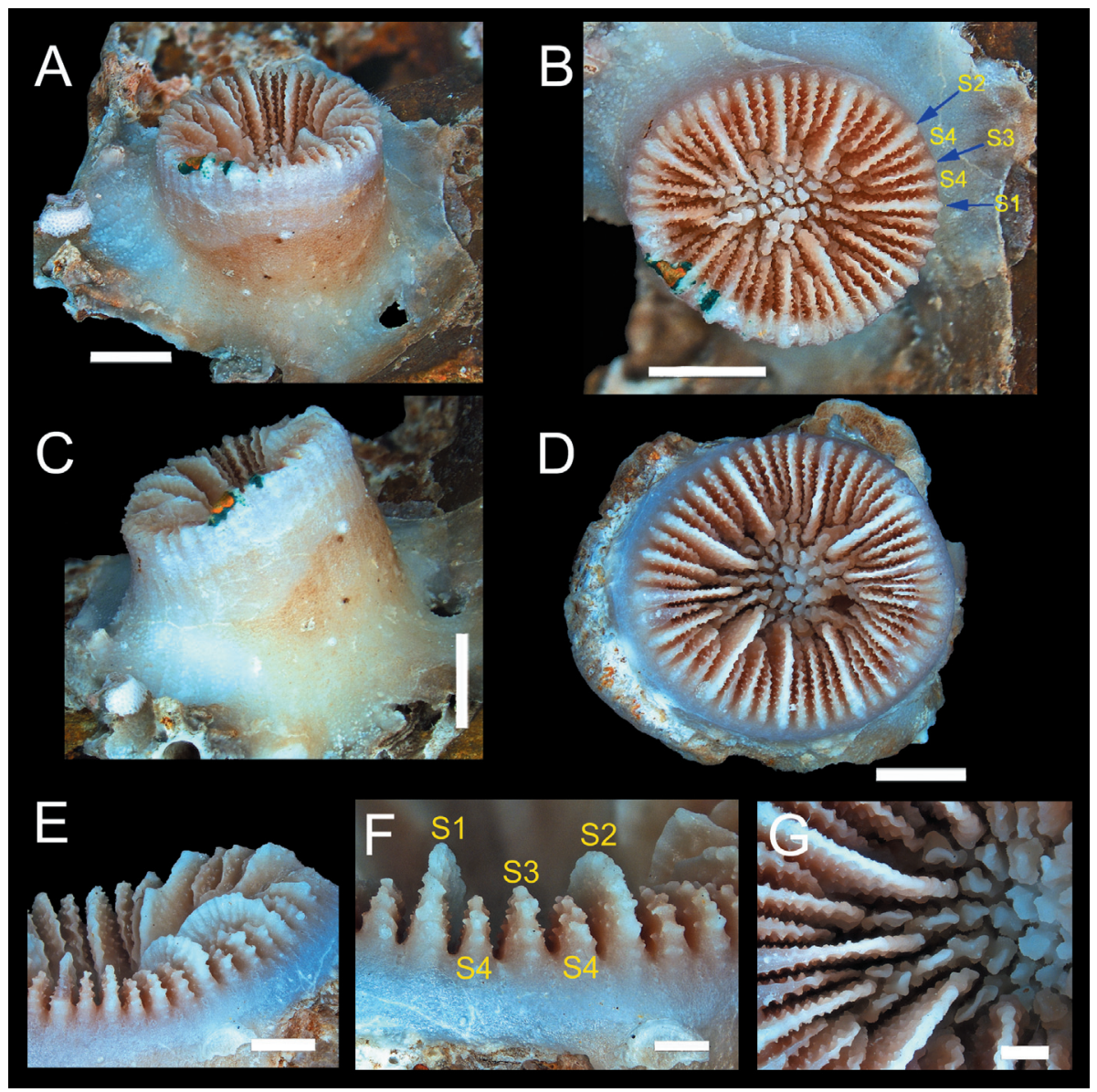

Fig. 1.- Coenocyathus cylindricus (MNCN, 2.04/390). A-C) Three images of the same specimen, including a calicular view (B). Note expanding basal plate over the substrate. D-G) Images of another specimen, including calicular view (D). Note ornamentation of septa $(E, F)$, and pali facing S3 (G). Scale bar: $A-D=2.0 \mathrm{~mm} ; \mathrm{E}=1.0 \mathrm{~mm} ; \mathrm{F}, \mathrm{G}=0.5 \mathrm{~mm}$.

Fig. 1.- Coenocyathus cylindricus (MNCN, 2.04/390). A-C) Tres imágenes de un mismo ejemplar, incluyendo una vista oral (B). Nótese la lámina basal extendiéndose por el sustrato. D-G) Imágenes de otro ejemplar, incluyendo una vista oral. D) Nótese la ornamentación de los septos (E, F), y los pali frente a $S 3(G)$. Escala: $A-D=2.0 \mathrm{~mm} ; E=1.0 \mathrm{~mm} ; \mathrm{F}, \mathrm{G}=0.5 \mathrm{~mm}$.

Coenocyathus cylindricus Milne Edwards \& Haime, 1848: 298, pl. 9, fig. 8.-Lacaze-Duthiers, 1897: 108, pl. 5, figs. 13-15._Zibrowius, 1980: 73, pl. 31, figs. A-L.—Zibrowius, 1983: 8.Cairns, 2000: 71. - Cairns \& Chapman, 2001: 35 (tab. 1).—Kružić et al., 2002: 349, fig. 4.—BouryEsnault et al., 2005: 21, 22, 23.-Zibrowius \& Taviani, 2005: 811 (tab. 2).-Braga-Henriques et al., 2013: 4015, 4027 (tab. A1), fig. A1.

Non Coenocyathus cylindricus: Rossi, 1960: 7, figs. 1-3. 
? Coenocyathus cylindricus: Gómez-Alba, 1988: 78, pl. 39, fig. 10, 10a.—Consejería de Obras Públicas y Vivienda, 2011; 291.-Gallemí et al., 2013: 64.

Material examined. MNCN 2.04/390, Campaña Fauna Ibérica II (1991), 14.06.1991, $43^{\circ} 40.59^{\prime} \mathrm{N}-43^{\circ} 40.25^{\prime} \mathrm{N} / 07^{\circ} 04.35^{\prime} \mathrm{W}-07^{\circ} 02.77^{\prime} \mathrm{W}$ (off Ribadeo, Lugo), 114-116 m, two dry, solitary specimens.

Description (specimen 1, Fig. 1A-C): Corallum solitary and short, almost cylindrical in side view, slightly arched, with $\mathrm{H}=4.3 \mathrm{~mm}$. Basal plate wide and thin, covering the substrate. Wall costate, with C1-C4 inconspicuous, subequal in width, flat, separated by shallow striae, and covered by low and round granules. Calice almost circular, with 46 septa; GCD = $5.8 \mathrm{~mm}, \mathrm{LCD}=5.0 \mathrm{~mm}$, and GCD/LCD $=1.16$. Septae scarcely exsert, hexamerally arranged in four cycles S1-S4 and six systems, with 2S4 lacking in one of the systems. S1 dominant, little exsert; S2 almost equally exsert than S1, and S3 and S4 notably less exsert. In some systems, septa are equally exsert. $\mathbf{S 1}$ slightly wider or almost equally wider than $\mathbf{S 2}$, these wider than S3, and these almost equal to S4. S1 extending a little bit or almost equally farther toward the columella than \$2, these than \$3 and these than \$4. In some systems, S3 and S4 extend similarly towards columella. Only S1 and some S2 reach the columella or nearly so, generally surpassing the level of the pali. Upper septal margins with apparent granules near calicular margin, otherwise more or less smooth; lateral faces granulated with apparent, pointed granules. Inner edges straight, descending vertically into the fossa, sinuous. Palar crown formed by 11P3 (one lacking); pali as small lobes, sinuous, with granular lateral faces. Fossa deep, containing a papillose columella slightly under the palar crown level. Corallum light brown to whitish.

Remarks. The other specimen is regenerated, and has a solitary and short corallum as well, with $\mathrm{H}=8.9 \mathrm{~mm}$ (Fig. 1D-G). Its proximal end is lacking. The wall is thick and smoother than in the other corallite, and is only slightly costate distally if so. Costae are subequal in width and are covered by inconspicuous low and round granules. The calice is almost circular and has 50 septa; GCD $=7.1 \mathrm{~mm}, \mathrm{LCD}=6.8 \mathrm{~mm}$ and GCD/LCD $=1.04$. The relative size and the arrangement of the septa are similar to the other specimen, although pali are comparatively smaller and there are irregularities in the allocation and size of the septa in some systems, perhaps due to the regeneration of the specimen (Fig. 1D). Besides, some septa are slightly curved (Fig. 1D, G).

The genus Coenocyathus is separated from its closely allied genus Caryophyllia Lamarck, 1801, mainly by its colonial habitus with extracalicinal budding (see Zibrowius, 1980). However, no trace of budding was observed in the specimen at study, although the arrangement of the calicular elements leaves no doubt about its identification.

The material was collected at 114-116 m depth and only the skeletons are remaining. Unfortunately, in the museum label it is not specified whether specimens were collected alive or not. Hence, it is uncertain if the species lives at the depth of collection in the Bay of Biscay, although this depth is within the range of 65-500 m given by Cairns \& Chapmann (2001) for this coral in the Eastern Atlantic. There are even shallower and deeper records as follows: Boury-Esnault et al. (2005, 6-8 to $18 \mathrm{~m}$ in caves, Portugal), Zibrowius \& Taviani 
(2005, 786 m, Strait of Sicily, Mediterranean Sea, dead specimens), and Kružić et al. (2002, 27-103 m depth, Adriatic Sea). Hence, the species lives on hard substrata from rather shallow depths in appropriate environments (caves), to the upper bathyal.

Neither of the two specimens was parasited by Megatrema anglicum (Sowerby, 1823), as noticed in Morocco by Zibrowius (1980).

Coenocyathus cylindricus is known from the Adriatic Sea, the western Mediterranean Sea, Portugal, the Azores, the Canary Islands, Morocco, Senegal and the Guinea Gulf (LacazeDuthiers, 1897; Zibrowius, 1980, 1983; Kružić et al., 2002; Moro et al., 2003; Boury Esnault et al., 2005; Zibrowius \& Taviani, 2005; Braga-Henriques et al., 2013). Its northernmost record is in the Bay of Biscay, being also the northern distributional limit of the genus.

\section{Discussion}

Two are the species of the genus Coenocyathus recorded in the northeastern Atlantic, C. cylindricus and C. anthophyllites. Although Coenocyathus dohrni Döderlein, 1913 has been frequently mentioned in the Mediterranean literature, it is now considered to be a synonym of Caryophyllia inornata (Duncan, 1878) (Zibrowius, 1980), a shallow-water species capable of forming pseudocolonies. Both species of Coenocyathus are poor known and infrequently collected (Rossi, 1960; Zibrowius, 1980), with specimens rarely described and depicted in the literature, although as noticed in the Introduction, C. cylindricus is widely distributed and inhabits a considerable depth range.

The northernmost record of the genus in mainland Europe corresponded to C. anthophyllites in Setubal, Portugal (Zibrowius, 1980), and the unique record of extant specimens of C. cylindricus in the Iberian Peninsula is from the south of Portugal. One record of this species by Rossi (1960), also from Portugal, was rejected by Zibrowius (1980) and partially attributed to C. anthophyllites. Hence, the genus is here first recorded in the Bay of Biscay, being also the northernmost record in the Eastern Atlantic. The only previous data of the species in Spanish waters was from the Canary Islands (Moro et al., 2003), although it has been listed in some Pliocenic deposits from Barcelona (Gómez-Alba, 1988; Gallemí et al., 2013) and Málaga (Consejería de Obras Públicas y Vivienda, 2011). However, and according to Zibrowius (1980), records of Coenocyathus from Miocenic and Pliocenic European deposits are not supported by a comparison with the type material. As far as the Spanish fossil specimens are concerned, these have not been described in detail.

Given its colonial habits and the arrangement of its calicular elements, this species can be hardly confused with any other in the Iberian Peninsula. Hence, the absence of records reflects its scarceness, especially considering that it occurs in a notable depth range from shallow depths to the upper bathyal.

Its presence in the Bay of Biscay is remarkable, as the deep-sea fauna of this area has been the subject of intensive research that revealed a high biodiversity. Updating Zibrowius (1980) paper (see Altuna, 2013; Altuna \& Ríos, 2014), and considering also C. cylindricus, 
currently there are 46 species (one species, Enallopsammia marenzelleri Zibrowius, 1973, doubtfully recorded) known from the southern sector of the Bay of Biscay ("I" sector of Zibrowius, 1980, 45N-43N), with 42 of them being deep-sea corals according to Cairns (2007), i.e., living below $50 \mathrm{~m}$ deep. The species richness of this sector is among the highest from the 20 sectors recognized by Zibrowius (1980) in the northeastern Atlantic and the Mediterranean Sea. There are some important factors to be taken in consideration for explaining this biodiversity. For instance, the southern sector has a great seafloor geomorphologic heterogeneity with favorable environments for enhanced biodiversity, like submarine canyons and banks, a predominance of rocky shores, and considerable a high depth. Cold-water coral banks are abundant in certain deep-sea areas as well. Besides, there are oceanographic features favoring upwellings and primary productivity (Gibson, 2005). Finally, there has been a great sampling effort in the area since the end of the $19^{\text {th }}$ century, particularly in the last years by the Spanish Institute of Oceanography (ECOMARG and INDEMARES projects), which produced large collections of material of high species richness. Moreover, given that some other species not yet recorded in the Bay of Biscay occur in the Galicia Bank and nearby areas (see Altuna, 2013), new records are expected to occur.

Among all the species occurring from the northern limit of the southern sector of Zibrowius $\left(1980,45^{\circ} \mathrm{N}\right)$ to the west of Ireland (sector " $\mathrm{H}$ " of Zibrowius, 1980), only Trochocyathus sp. (Tyler \& Zibrowius, 1992, 2800 m depth, based on bottom photographs), has not yet been recorded from the southern sector off Spain. However, the species richness of this northern sector " $H$ " is significantly lower, with several scleractinians not yet recorded at latitudes higher than $45^{\circ} \mathrm{N}$.

\section{Acknowledgements}

Thanks are due to Javier Sánchez (MNCN) for sending the samples, to Helmut Zibrowius for his comments on the species, and to the anonymous referees that improved the manuscript. Nagore Otamendi and Florencio Aguirrezabalaga helped with the translation of the text.

\section{Bibliography}

- Altuna, Á., 2013. Deep-water scleractinians (Cnidaria: Hexacorallia) collected by the ECOMARG 2003, 2008 and 2009 expeditions in the Bay of Biscay (Le Danois Bank, Avilés Canyon), and the Galicia Seamount (north-eastern Atlantic). Zootaxa 3641: 101-128.

- Altuna, Á., Ríos, P. 2014. Scleractinia (Cnidaria: Anthozoa) from INDEMARES 2010-2012 expeditions to the Avilés Canyon System (Bay of Biscay, Spain, northeast Atlantic). Helgol. Mar. Res. 68: 399-430. 
- Boury-Esnault, N., Harmelin, J.G., Ledoyer, M., Saldanha, L., Zibrowius, H. (2001) 2005. Peuplement benthique des grottes sous-marines de Sagres (Portugal, Atlantique nord-oriental). Bol. Mus. Mun. Funchal (Supl.) 6: 13-38.

- Braga-Henriques, A., Porteiro, F.M., Ribeiro, P.A., de Matos, V., Sampaio, Í., Ocaña, O., Santos, R.S. 2013. Diversity, distribution and spatial structure of the cold-water coral fauna of the Azores (NE Atlantic). Biogeosciences 10: 4009-4036.

- Cairns, S.D. 2000. A revision of the shallow-water azooxanthellate Scleractinia of the Western Atlantic. Stud. Nat. Hist. Caribb. Reg. 75: 1-240.

- Cairns, S.D. 2007. Deep-water corals: an overview with special reference to diversity and distribution of deep-water scleractinian corals. Bull. Mar. Sci. 81: 311-322.

- Cairns, S.D., Chapman, R.E. 2001. Biogeographic affinities of the North Atlantic deep-water Scleractinia. Proceedings of the First International Symposium on Deep-Sea Corals. Halifax: 30-57.

- Consejería de Obras Públicas y Vivienda. 2011. Orden de 28 de julio de 2011, por la que se dispone la publicación de la Normativa Urbanística de la Revisión-Adaptación del Plan General de Ordenación Urbanística de Málaga, aprobada por Orden de 21 de enero de 2011. BOJA 170: 1-1160.

- Gallemí, J., Vicedo, V., López, G., Troya, L. 2013. La col·lecció paleontològica Gómez-Alba del MGB-MCNB. Treb. Mus. Geol., Barcelona 19: 59-149.

- Gibson, L. 2005. A critical evaluation of the Bay of Biscay as a candidate for a Marine Protected Area. MsC thesis. University of Wales. Bangor.

- Gómez-Alba, J. 1988. Guía de campo de los fósiles de España y de Europa. Ediciones Omega. Barcelona.

- Kružić, P., Zibrowius, H., Požar-Domac, A. 2002. Actiniaria and Scleractinia (Cnidaria, Anthozoa) from the Adriatic Sea (Croatia): first records, confirmed occurrences and significant range extensions of certain species. Ital. J. Zool. 69: 345-353.

- Lacaze-Duthiers, H. 1897. Faune du Golfe de Lion. Zoanthaires Sclérodermes (deuxième mémoire). Arch. Zool. Exp. Gén. (3) 5: 1-249, pls. 1-12.

- Milne-Edwards, H., Haime, J. 1848. Recherches sur les polypiers. Deuxième mémoire: Monographie des Turbinolides. Ann. Sci. Nat., Zoologie (3) 9: 211-344, pl. 7-10.

- Moro, L., Martín, J.L., Garrido, M.J., Izquierdo, I. (Ed.) 2003. Lista de especies marinas de Canarias (algas, hongos, plantas y animales) 2003. Consejería de Política Territorial y Medio Ambiente del Gobierno de Canarias. La Laguna.

- Rossi, L. 1960. Madréporaires. Résult. Scient. Camp. "Faial" Portugal (1957) 3: 1-13.

- Templado, J., Guerra, A., Bedoya, J., Moreno, D., Remón, J.M., Maldonado, M., Ramos, M.A. 1993. Fauna marina circalitoral del sur de la Península Ibérica. Museo Nacional de Ciencias Naturales. Madrid. 
- Tyler, P.A., Zibrowius, H. 1992. Submersible observations of the invertebrate fauna on the continental slope southwest of Ireland (NE Atlantic Ocean). Oceanol. Acta 15: 211-226.

- Zibrowius, H. 1980. Les Scléractiniaires de la Méditerranée et de l'Atlantique nord-oriental. Mém. Inst. Océanogr., Monaco 11: 1-284, pls. 1-107.

- Zibrowius, H. (1981) 1983. Scléractiniaires récoltés par R.Ph. Dollfus sur la côte atlantique du Maroc. Campagnes du "Vanneau"1923-1926. Bull. Inst. Scient., Rabat 5: 1-12.

- Zibrowius, H., Taviani, M. 2005. Remarkable sessile fauna associated with deep coral and other calcareous substrates in the Strait of Sicily, Mediterranean Sea. In: Cold-water Corals and Ecosystems. A. Freiwald, J.M Roberts (Ed.): 807-818. Springer-Verlag. Berlin. 